\title{
Contextualisation of Humanitarian Assistance and its Shortcomings in International Human Rights Law
}

Anicée Van Engeland*

\section{ABSTRACT}

This paper challenges the idea that contextualisation of humanitarian aid affects the principle of universality of human rights as well as the principles of neutrality and impartiality. It seeks to demonstrate that contextualisation will not only improve access, delivery and protection: contextualising a mission also enables aid workers to respect the local context without impacting universal human rights negatively. The author argues that impacting the societies in which aid is delivered is inevitable. The key then becomes to avoid endorsing indirect cultural relativism. This is why the article puts forward the idea of creating a yardstick or a test that would help deciding which beliefs and values are to be included when considering the context, and which ones should be excluded. The process of selection of values and beliefs is to be operated by an empowered local population. The filter suggested in the case at hand is the Muslim legal instrument of maslaha that protects the public interest. The use of this filter can only be efficient if Islamic authoritative sources are interpreted differently, in a reformist fashion, to try and match universal human rights law. This is possible through the Muslim theories advocating for change. Muslim beneficiaries who are vulnerable after a disaster or during a conflict provide an opportunity to test the filter of maslaha, looking at how an empowered community can change and influence aid agencies' agenda.

\section{KEYWORDS}

humanitarian assistance, human rights, religion, culture, Islam

\section{INTRODUCTION}

\footnotetext{
${ }^{*}$ Dr Anicée Van Engeland is an invited academic at the Centre for Socio-Legal Studies at the University of Oxford and a Lecturer in Law at Cardiff University. She can be contacted at anicee.vanengeland@csls.ox.ac.uk
} 
Several current theatres of operations call for some consideration of the cultural or religious context: in Afghanistan, different organizations have realised the importance of understanding the ethnic patchwork; in Nepal, the United Nations Development Programme (UNDP) seeks to accommodate informal justice systems; organizations are aware that Syrian refugees suffer from additional stress due to their feeling of powerlessness regarding change in traditional gender roles. The issue of taking beliefs and values into account becomes even more pressing when faced with international human rights violations, such as sewn women in Somalia. Therefore, aid workers operate in a world in which culture, religion, customs and/or traditions impact access, delivery and protection. The impact of beliefs and values on humanitarian missions is partly explained by the role religions and cultural beliefs have played in contributing to the development of humanitarianism. ${ }^{1}$ The influence can also be explained by religious missionaries' legacy. ${ }^{2}$ Nowadays, the issue originates from the context organizations operate within. Organizations find themselves caught between the need for 'cultural authenticity $^{3}$, and the respect for universal human rights law. I argue that the delivery of aid and the protection of beneficiaries will be improved if organizations contextualise their missions. The issue is then to decide how beliefs and values can be included in aid organizations' strategies without harming universal human rights. This article seeks to demonstrate that contextualisation will not only improve access, delivery and protection of humanitarian assistance: contextualising a mission also enables aid workers to respect the local context without impacting universal human rights negatively.

The interest in contextualising missions is recent. ${ }^{4}$ For several organizations, values and beliefs are still considered a subjective factor that impacts the principles of neutrality and impartiality. Yet, the role of beliefs and values cannot and should not be ignored as they provide a framework for effective humanitarian assistance. ${ }^{5}$ It remains that considering them

\footnotetext{
${ }^{1}$ Eleanor Davey and Eva Svoboda, Histories of Humanitarian Action in the Middle East and North Africa (Overseas Development Institute 2014); Avery Cardinal Dulles, 'Christianity and Humanitarian Action' in Kevin M Cahill (ed), Traditions, Values and Humanitarian Action (Fordham University Press and The Center for International Health and Cooperation 2003) 5.

2 The Centre on Conflict, Development and Peacebuilding, 'Religion and Humanitarianism: Floating Boundaries in a Globalizing World', Conference Report, 10-11 October 2009, 5, http://graduateinstitute.ch/files/live/sites/iheid/files/sites/ccdp/shared/Docs/Publications/Conf_Report_DEF_LR. pdf.

${ }^{3}$ Gerard Clarke, 'Faith-Based Organisations and International Development: An Overview' in Gerard Clarke and Michael Jennings (eds), Development, Civil Society and Faith-Based Organisations: Bridging the Sacred and the Secular (Palgrave Macmillan 2008) 17.

${ }^{4}$ Gerard Clarke, 'Agents of Transformation? Donors, Faith-Based Organisations and International Development' (2007) 28 Third World Quarterly 77, 78.

${ }^{5}$ Andrea Paras and Janice Gross Stein, 'Bridging the Sacred and the Profane in Humanitarian Life' in Michael Barnett and Janice Gross Stein (eds), Sacred Aid: Faith and Humanitarianism (Oxford University Press 2012) 211.
} 
raises operational issues as well as legal issues: contextualising could be perceived as negatively impacting the principle of universality of human rights and as an acknowledgement of cultural relativism. So, while I argue that contextualisation is necessary, there needs to be a limit in the form of a benchmark or a test whereby the accommodation of local beliefs and values is not possible as it harms universal human rights law.

My suggestion is to firstly shift the focus from external actors, here humanitarian organizations, to local communities and to examine how they develop instruments to approach mores. I use Islam and Islamic law as a case study, and suggest analysing to role of a legal tool used by Muslim: the principle of maslaha, or public interest. I will look at how communities have used this instrument as a filter to decide which mores should or should not be considered; I then encourage aid agencies to look into the work done by the communities to give them information about the current context. The focus on a bottom-up creation of mores is important as Muslim local communities find themselves at a crossroads in terms of reforms ${ }^{6}$ and they constitute potential powerful agents of change, as developed below in this article. My overall suggestion is that aid agencies need to be aware of the context to develop programs that will support such changes, rather than hinder them. It is important to acknowledge the reluctance of aid agencies in contextualising for fear of having a transformative agenda. The use of a local filter to select values will put this worry to rest.

The originality of the article is found in a twist to Benthall's idea of cultural proximity by developing a cross-cultural approach: ${ }^{7} \mathrm{I}$ argue that considering the context could potentially provide humanitarian organizations with an opportunity to build bridges between universal human rights and local understandings of human rights, which will in turn create opportunities for access, protection and delivery. This leads me to question vulnerability at times of conflicts and disasters (or the cross-over between the two): I explain that such environments provide an opportunity to empower local players into monitoring and directing the evolution of cultural, traditional and religious norms in terms of universal human rights instead of falling back onto these norms for protection. However, contextualisation can only occur through a selection of beliefs and values; I will operate this selection via a test, looking at Islam and women's rights in particular. I also call for a limit to the consideration of beliefs

\footnotetext{
${ }^{6}$ Abdullahi Ahmed An-Na'im, Islam and the Secular State: Negotiating the Future of Shari'a (Harvard University Press 2008) 1-44.

${ }^{7}$ Jonathan Benthall, 'Humanitarianism and Islam after 11 September' in Joanna Macrae and Adele Harmer (eds), Humanitarian Action and the 'Global War on Terror': A Review of Trends and Issues (Overseas Development Institute 2003) 37.
} 
and values, seeking an answer to Donaldson's question: '[w]hen is different just different, and when is different wrong? ${ }^{\prime 8}$

\section{THE NEED FOR CONTEXTUALISING HUMANITARIAN MISSIONS}

I will firstly explain why it is important to contextualise and what organizations could gain from contextualisation. I will then address Benthall's doctrine of cultural proximity; his argument is that Muslim faith-based organizations (FBOs) can provide more effective and sensitive humanitarian aid in Muslim areas because of their knowledge of Islam. I will examine his doctrine to see whether FBOs benefit from an advantage because they contextualise.

\subsection{The Purpose of Contextualisation is to Improve Access, Protection and Delivery}

Each humanitarian mission takes place in a specific context which can be cultural, religious, traditional, political, social or economic. While the principles of neutrality and impartiality have been put forward by many organizations, the reality of the field has caught up with aid workers: they often face issues accessing beneficiaries, protecting people or delivering aid because of the context. For example, any organizations working in Afghanistan needs to consider ethnic belonging, religion, culture, customary law and traditions to have a successful mission: the distinction between Hazaras and Pashtuns shapes the country and must be weighed when preparing an aid mission. There can be a plurality of values and identity, ${ }^{9}$ leading to variations that affect humanitarian aid and is sometimes a matter of life and death for workers or beneficiaries: when women from different ethnic groups contributed to the 2000 All Party Burundi Women's Peace Conference supported by the United Nations Development Fund for Women (UNIFEM), some took great risks travelling to the location of the meeting or were criticised for meeting in the public eye and discussing gender issues. ${ }^{10}$ Another illustration highlighting the importance of understanding the context can be found during the 1998 Sudan famine: aid workers were under the impression that the food they were distributing was given to tribal leaders, and thus concluded that the local culture of corruption

\footnotetext{
${ }^{8}$ Thomas Donaldson, 'Values in Tension: Ethics Away from Home' (1996) 74(5) Harvard Business Review 48.

${ }^{9}$ Kevin Avruch, Culture and Conflict Resolution (United States Institute of Peace Press 1998) 20.

${ }^{10}$ Noeleen Heyzer, 'Women on the Front Lines: UNIFEM's Work to Promote Women, Peace and Security' in Yael Danieli (ed), Sharing the Front Line and the Back Hills: International Protectors and Providers: Peacekeepers, Humanitarian Aid Workers and the Media in the Midst of Crisis (Baywood Publishing Company 2002) 85,89 .
} 
was so entrenched that they would struggle feeding individuals. An anthropologist was recruited to understand the phenomenon; he discovered that while all members of the tribe would give their food rations to the leader, the latter would divide the food equally amongst all the people. This means that the most vulnerable individuals were not getting the attention they needed. As a result, members of the group were slowly starving together as the rations were not given according to the individual needs, but were distributed equally. Markus and Conner concluded that aid workers had been trained to focus on severe individual malnutrition cases and had missed the collective factor which led to group starvation. ${ }^{11}$ The lack of contextualisation also led to the erection of new houses in the post tsunami period without carrying out environmental impact and cultural assessments in areas that were too far from the sea for fishermen, depriving them from their source of income. ${ }^{12}$ Had the organizations conducted a proper environmental assessment and had they spoke to the locals who know the shores, they would have improved the delivery of aid by building houses close enough to the sea so that fishermen could have kept their occupation, while being in a secure location. Another illustration is to be found in Darfur where potable water and groundwater were separated and located at other ends of a camp, forcing women collecting wood to walk along the margins of the camp to avoid passing by the showers and toilets; it emerged they could be harassed by men when passing near showers, and they walked around the showers, exposing themselves to possible violence of armed groups lurking nearby. ${ }^{13}$ Dowty also reports the delivery on non-halal food in Muslim areas of Thailand. ${ }^{14}$ These few examples demonstrate that access, delivery and protection could have been improved had the organizations worked with locals and take into account their beliefs and values to better assess the needs. Contextualising is therefore a challenge for foreign workers. ${ }^{15}$ Including beliefs and values when programming is vital: ${ }^{16}$

\footnotetext{
${ }^{11}$ Alana Conner and Hazel Rose Markus, Clash!: 8 Cultural Conflicts That Make Us Who We Are (Hudson Street Press 2013).

12 Jim Kennedy, Joseph Ashmore, Elizabeth Babister and Dr Ilan Kelman, 'Post-Tsunami Transitional Settlement and Shelter: Field Experience from Aceh and Sri Lanka', Humanitarian Exchange Magazine, March 2007, http://odihpn.org/wp-content/uploads/2007/04/humanitarianexchange037.pdf.

${ }^{13}$ Rachel A Dowty, 'Humanitarian Logistics: A Cultural Perspective' in Martin Christopher and Peter Tatham (eds), Humanitarian Logistics: Meeting the Challenge of Preparing for and Responding to Disasters (Kogan Page 2011) 201, 207.

${ }_{14}^{14}$ ibid.

${ }^{15}$ Brian W Flynn, 'Disaster Mental Health: The U.S. Experience and Beyond' in Jennifer Leaning, Susan M Briggs and Lincoln C Chen (eds), Humanitarian Crises: The Medical and Public Health Response (Harvard University Press 1999) 97, 118-19.

${ }^{16}$ Pierre Gassmann, 'Rethinking Humanitarian Security', Humanitarian Exchange Magazine, June 2005, 33, http://odihpn.org/wp-content/uploads/2005/07/humanitarianexchange030.pdf.
} 
More often than not, the security incidents suffered by aid agencies are due to foolish mistakes by ill-prepared individuals, and to faulty appraisals of local conditions [...] Most agencies admit that they have insufficient knowledge of the contexts in which they operate, that they lack local networks and information sources and that most of their international staff are not familiar with local customs, language and culture.

The issue for many organizations is to decide how far they will go when contextualising: while many will agree that the example of food distribution in Sudan requires some local coordination, others will be reluctant to consider beliefs and values impacting gender perceptions in Burundi. The dilemma between neutrality and context-based programs can be solved by examining the context without letting it influence actions: the International Committee of the Red Cross (ICRC) has worked on meeting beneficiaries' urgent needs in Sudan and in Somalia by working with local organizations and systems to avoid duplication of efforts: ${ }^{17}$ contextualisation was then limited by working with locals, but did not extent to locals' knowledge of food distribution. This allows for a better strategy and delivery without letting the context dictate programming. Still, there are situations in which organizations are pressured to contextualise directly, rather than externally as the ICRC has done, without the possibility to rely on local organizations. While most organizations will agree to encouraging local participation during aid missions, very few foreign organizations concur that they should develop a contextualised strategy, such as a gender-oriented strategy that confronts religion. They prefer working with the 'one-sizefits all model', and only take local specificities into account if the programs do not transform society. ${ }^{18}$ Aid workers indeed fear altering societal structures by relying on a transformative agenda. I argue that the reality of the field is that ' $[\mathrm{e}] \mathrm{xtraordinary}$ events [...] may result in behavior that deviates substantially from social norms or personal standards': ${ }^{19}$ a society will be impacted by a conflict or a disaster, and will change. The

\footnotetext{
${ }^{17}$ Pierre Perrin, 'The Impact of Humanitarian Aid on Conflict Development' (1998) 38 International Review of the Red Cross 319, 330.

18 Jonathan Whittall, 'Opinion and Debate: Either... Or - Building Resilience is Still not Compatible with Humanitarian Aid', 12 March 2014, http://www.msf.org.uk/article/opinion-and-debate-either\%E2\%80\%A6-orbuilding-resilience-still-not-compatible-humanitarian-aid; Samir Elhawary, 'Eroding Humanitarian Principles: Who's to Blame?', Humanitarian Practice Network, 7 August 2008, http://odihpn.org/blog/erodinghumanitarian-principles-who\%C2\%92s-to-blame/.

${ }^{19}$ Judy A Benjamin, 'Issues of Power and Gender in Complex Emergencies' in Kevin M Cahill (ed), Emergency Relief Operations (Fordham University Press and The Center for International Health and Cooperation 2003) $153,157$.
} 
presence of foreign actors will change the social structures, ${ }^{20}$ especially in a framework where aid workers are reflecting on 'how to stay' rather than 'when to leave'. ${ }^{21}$ To 'stay and deliver' also means to have an impact on the populations: in Haiti, the Canadian Center for International Studies and Cooperation invested to develop reliance on local products, therefore strengthening local agriculture and transportation systems. The project built upon existing agricultural structures and changed them by encouraging the transformation of grains and cereals, empowering new economic actors and modifying the diets of Haitians. ${ }^{22}$ Another illustration that deals less with development and addresses humanitarian care is the exclusion of traditional forms of medicine, ${ }^{23}$ perhaps leading to their disappearance. Such examples call for the demystification of a neutral type of humanitarian operation: the mere presence of foreign organization on a territory will alter the area as aid has a socio-political, economic and cultural impact.

Another aid workers' worry is the indirect support to human rights violations when considering local beliefs and values. I argue that, far from advocating cultural relativism, organizations that contextualise their operations allow for the respect of some beliefs and values. It is actually by not considering the local mores that the aid organizations can harm the communities: it is when they ignore local mores that aid agencies harm the local population. Speaking of gender based violence (GBV) in Afghanistan, Benard reports: ${ }^{24}$

The outcome of the discussion was always the same. There was nothing you could do about it, the aid workers regretfully concluded. You weren't there to interfere in people's cultural traditions. The Pashtuns were just like that. You couldn't change them. It was pointless to offer services that would benefit women, because the Afghans just didn't want that. They were used to things being this way. Even the women themselves didn't expect anything different.

\footnotetext{
${ }^{20}$ Mark Duffield, Global Governance and the New Wars: The Merging of Development and Security (Zed Books 2001) 121; Sarah Collinson and others, Paradoxes of Presence: Risk Management and Aid Culture in Challenging Environments (Overseas Development Institute 2013).

${ }^{21}$ Jan Egeland, Adele Harmer and Abby Stoddard, To Stay and Deliver: Good Practice for Humanitarians in Complex Security Environments (Policy Development and Studies Branch, UN Office for the Coordination of Humanitarian Affairs 2011).

${ }^{22}$ Kathy Mangones, 'Alternative Food Aid Strategies and Local Capacity Building in Haiti' in Ian Smillie (ed), Patronage or Partnership: Local Capacity Building in Humanitarian Crises (Kumarian Press 2001) 51, 65.

${ }^{23}$ Carlos Martin Beristain, Humanitarian Aid Work: A Critical Approach (University of Pennsylvania Press 2006) 152.

${ }^{24}$ Cheryl Benard, Veiled Courage: Inside the Afghan Women's Resistance (Broadway Books 2002).
} 
Benard then goes on to investigate the matter, only to realise that there were successful female-focused aid programs in the country and that Afghan women were asking for gender equality. This demonstrates that by refusing to engage with the mores, aid workers actually contribute to supporting the paternalistic control of the women through so-called cultural, traditional, customary or religious values, at the expenses of women's wishes. Not only do aid workers indirectly support an oppressive system, they also indirectly perpetuate the colonialist idea that mores cannot change.

Rather than ignoring this call for adapting to the environment, many organizations have contextualised to some degree. Taking the reality into account can be done through culturemapping as illustrated by the efforts of the ICRC to understand Muslim humanitarian standards. ${ }^{25}$ Meanwhile, the congruence between the two legal systems or the influence of Islamic law over international law is not discussed due to fears of fragmentation of international law. This mainstream approach of working on commonalities is summed up by Caney: ${ }^{26}$

\begin{abstract}
All cultures, be they Islamic, Hindu, Buddhist, secular or Christian, value the sanctity of human life. Similarly, it is difficult to think of any culture that welcomes drought, famine, disease, murder and malnutrition. Consequently cosmopolitan principles of humanitarian intervention that seek to eradicate these are not imposing values on societies which those societies reject.
\end{abstract}

The rejection of contextualisation or the use of a limited cultural-mapping also accommodates the view that FBOs and local organizations are more efficient when it comes to context since they engage with it on a regular basis. ${ }^{27}$

I believe that this reluctance to fully engage with the context has negative effects. Contextualisation through culture-mapping will help avoiding mistakes. It is necessary to understand the psychological limbo Syrian male refugees currently face. Their role as the bread-winner and the head of the family is being challenged by new circumstances, causing

\footnotetext{
25 ICRC, 'Iran: Dialogue on Islam and International Humanitarian Law in Qom', 1 December 2006, https://www.icrc.org/eng/resources/documents/feature/2006/ihl-islam-event-011206.htm.

26 Simon Caney, 'Human Rights and the Rights of States: Terry Nardin on Nonintervention' (1997) 18 International Political Science Review 27, 34.

${ }^{27}$ Jonathan Benthall and Jerome Bellion-Jourdan, The Charitable Crescent: Politics of Aid in the Muslim World (I B Tauris 2003) 125.
} 
depression. ${ }^{28}$ Appreciating the cultural and traditional gender context, without abiding by it or encouraging it as explained below, is crucial: these men who have lost everything, including their dignity as male and patriarch, must be helped. Avruch speaks of the necessity to be 'culturally competent ${ }^{\text {'2 }}$ in such circumstances, by developing cultural skills that will impact the success of the mission: it will create a mutual understanding between the host and the foreign actors. This attitude needs to stem from a genuine desire to accommodate culture, religion and other beliefs and values rather than from a desire to use culture as a strategic tool to access, protect and deliver. ${ }^{30}$ Positive examples include the delivery of medical help in countries where women are not supposed to be treated by male doctors and nurses. In such environments, I believe it is necessary to train the teams to the obstacles they will encounter, to encourage organizations to send female medical staff as well as having two entrance doors, one for females and one for males. For example, work has been done to educate the medical staff to issue of modesty to understand how it affects people's decisions to seek medical help. ${ }^{31}$ Seibert and his team elaborated a checklist to help cultural awareness, including using a translator, referring to the right religious referents and providing a relevant diet. ${ }^{32}$

There is a limit to cultural-mapping and to the degree to which we can contextualise a mission. Such obstacles explain why some have argued that FBOs are more efficient when it comes to contextualising humanitarian assistance.

\subsection{Does the Doctrine Cultural Proximity Gives an Advantage to FBOs over Foreign Organizations?}

To address the issue of context-based humanitarian actions, Benthall has elaborated the concept of 'cultural proximity ${ }^{33}$ when examining the growth of Islamic charities: he explains that Muslim organizations are in a better position to help Muslims than foreign organizations because of their knowledge of the field and the population. While FBOs do not hold per se an

\footnotetext{
${ }^{28}$ Roula El-Masri, Claire Harvey and Rosa Garwood, Shifting Sands: Changing Gender Roles Among Refugees in Lebanon (Oxfam International 2013) 15.

${ }^{29}$ Kevin Avruch, 'Culture as Context, Culture as Communication: Considerations for Humanitarian Negotiators' (2004) 9 Harvard Negotiation Law Review 391, 394.

${ }^{30}$ Alastair Iain Johnston, 'Thinking about Strategic Culture' (1995) 19(4) International Security 32.

${ }^{31}$ Caryn Scheinberg Andrews, 'Modesty and Healthcare for Women: Understanding Cultural Sensitivities' (2006) 3 Community Oncology 443; Paul Lawrence and Cathy Rozmus, 'Culturally Sensitive Care of the Muslim Patient' (2001) 12 Journal of Transcultural Nursing 228.

${ }^{32}$ P S Seibert, P Stridh-Igo and C G Zimmerman, 'A Checklist to Facilitate Cultural Awareness and Sensitivity' (2002) 28 Journal of Medical Ethics 143.

33 Jonathan Benthall, 'Humanitarianism and Islam after 11 September' in Joanna Macrae and Adele Harmer (eds), Humanitarian Action and the 'Global War on Terror': A Review of Trends and Issues (Overseas Development Institute 2003) 37.
} 
advantage over foreign organizations, ${ }^{34}$ it has been noted that the former, when operating in a domestic context or a familiar context, are more efficient than the latter: ${ }^{35}$ Benthall argues, looking at the example of Islamic Relief in Banda Aceh in a post tsunami operation, ${ }^{36}$ that the community tend to trust more a team composed of Muslim believers. My aim is to complete the doctrine by looking at the role non-Muslim organizations can play, demonstrating that they can also gain a better access and provide better protection by getting some knowledge of Islam.

It is a reality that the behavior of FBOs' staff members will differ from the one of foreign organizations: tensions will naturally emerge when empty bottles of alcohol consumed by foreign organizations' staff are disposed of in the streets during a disaster period. ${ }^{37}$ Muslim beneficiaries, made vulnerable by the loss of daily indictors, find yet another challenge in their conditions through the exhibition of alcoholic behavior. The conclusion reached by Benthall is that FBOs have a cultural proximity with beneficiaries which enhances their access as well as enables them to provide better protection of local populations and delivery of aid. This is why James argues that it is better to have FBOs deployed to reach the most vulnerable faster. ${ }^{38} \mathrm{He}$ also notes that FBOs are in a better position to empower local actors and support the community, transforming the society within boundaries known by the aid workers and the beneficiaries. This doctrine of cultural proximity provides the background to the increased role of FBOs and local organizations. ${ }^{39}$

With this concept of cultural proximity, Benthall provides an extension of the concept of Ummah according to which Muslims universally help other Muslims. ${ }^{40}$ While this rests on the existence of a Muslim principle, the Benthall's doctrine does not take into account the multiplicity of interpretations that leads to disagreements within the Ummah. The dividing issues can be political or religious. Palmer explains that sharing a common religion will not always be helpful when there are other divisions, such as ethnic, cultural or traditional

\footnotetext{
${ }^{34}$ Bertrand Taithe, 'Pyrrhic Victories? French Catholic Missionaries, Modern Expertise, and Secularizing Technologies' in Barnett andStein (n 5) 166, 188.

35 Jonathan Benthall, "“Cultural proximity" and the Conjuncture of Islam with Modern Humanitarianism' in Barnett and Stein (n 5) 65.

${ }^{36}$ Jonathan Benthall, 'Have Islamic Aid Agencies a Privileged Relationship in Majority Muslim Areas? The Case of Post-Tsunami Reconstruction in Aceh', The Journal of Humanitarian Assistance, 26 June 2008 , http://sites.tufts.edu/jha/archives/153.

${ }^{37}$ Shirley A Fedorak, Global Issues: A Cross-Cultural Perspective (University of Toronto Press 2013$) 34$.

${ }^{38}$ Rick James, 'What is Distinctive about FBOs? How European FBOs Define and Operationalise their Faith', INTRAC, February 2009, 7, http://www.intrac.org/data/files/resources/482/Praxis-Paper-22-What-is-DistinctiveAbout-FBOs.pdf.

${ }^{39}$ Scott M Thomas, The Global Resurgence of Religion and the Transformation of International Relations: The Struggle for the Soul of the Twenty-First Century (Palgrave Macmillan 2005).

${ }^{40}$ Benthall (n 36) 65.
} 
differences. ${ }^{41}$ Besides, this attempt from a member external to the Ummah at developing an Islamic concept lacks legitimacy: to be accepted by the Ummah, the concept of cultural proximity should have been developed on a Quranic basis and on an organic basis. The other issue with the idea of cultural proximity is that it clearly sidelines any organization that does not embrace a religion or a culture. I do not believe it is necessary for all organizations to adopt a local discourse to address humanitarian issues. Consequently, relying mainly on local FBOs is not sufficient; it is necessary to acknowledge that foreign organizations have a different expertise to FBOs and should retain access to beneficiaries. It would be ludicrous to claim that any FBO could replace the work done by Médecins Sans Frontières (MSF), which is not Benthall's claims: rather FBOs complete the work done by international or foreign organizations. ${ }^{42}$ Yet, the idea of cultural proximity could help build bridges between the communities, as developed in part 3 of this article.

The promotion of cultural relativism is an issue pertaining to FBOs: some FBOs hold a discourse which contradicts universal human rights as they support divinely rooted rights and justify violations of human rights on the basis of mores. Some FBO's programming includes values and beliefs that would be repugnant to human rights. As a result, there is a risk to give FBOs too much power or legitimacy: it would equal to giving them a free hand in the perpetuation of beliefs and values that violate human rights. For example, some FBOs might exclude women from programmes, or address their needs through the scope of the family, therefore reducing them to the gendered role of mother and wife. By allowing such organizations to be the only ones, or the main ones, to deal with context, we could indirectly support GBV and discrimination against minorities. In rural Rajasthan, FBOs play a crucial role. They still rely on traditional religious readings of authoritative sources of Islam, ${ }^{43}$ excluding women from public decision-making forums. ${ }^{44}$ These FBOs also fail to address issues such as domestic violence. ${ }^{45}$ It is a reality that there are situations in which FBOs have

\footnotetext{
${ }^{41}$ Victoria Palmer, 'Analysing Cultural Proximity: Islamic Relief Worldwide and Rohingya Refugees in Bangladesh' (2001) 21 Development in Practice 96.

${ }^{42}$ Elizabeth Ferris, 'Faith-Based and Secular Humanitarian Organizations' (2005) 87 International Review of the Red Cross 311, 325.

${ }^{43}$ The authoritative sources are the Quran and the Sunna as primary sources, followed by Ijma and Qiyas as secondary sources. The Quran is the Holy Book of Islam. It must be interpreted by scholars to be applicable. The Sunna is the sayings, acts and deeds of the Prophet as reported by his companions. These are the primary sources interpreters refer to. They then practice ijtihad, the effort of interpretation, through ijma which is a collective consensus of interpretation. Interpreters can also work alone, practicing the qiyas or deductive analogy. Interpreters use a rule stated in the Quran or found in the Sunna to apply it to a new problem.

${ }^{44}$ Mary Nyangweso Wangila, Female Circumcision: The Interplay of Religion, Gender and Culture in Kenya (Women from the Margins) (Orbis Books 2007).

${ }^{45}$ Tamsin Bradley, Religion and Gender in the Developing World: Faith-Based Organizations and Feminism in India (I B Tauris 2011).
} 
used their knowledge of the context to improve the respect of human rights, such as the Inner Circle Ministers in South Africa which has supported lesbian, gay, bisexual and transgender communities. ${ }^{46}$ Yet, too often, these organizations are prone to using interpretations suiting an agenda. As a result, work is now being done on how FBOs could be reformed ${ }^{47}$ to better engage with the principles of neutrality and impartiality, and step away from cultural relativism. ${ }^{48}$ The biopolitics of these organizations needs to be scrutinised to understand their nature and mandate. Benthall's typology of FBOs is useful as it makes the distinction between the organizations that seek to manipulate or influence a context with those that are fully committed to aid. ${ }^{49}$ My view on FBOs is that they play an important part, especially with regard to encouraging and supporting positive transformative changes into society, as explained below. Yet, contextualisation should not be left to FBOs alone, as they are by nature subjective agencies.

I have now established why contextualisation is necessary. The academic attempt to frame it in a Muslim context needs to be further developed. Benthall's idea of cultural proximity of FBOs needs to be completed by looking at the role foreign organizations can play when it comes to contextualisation. Yet, before looking into ways of approaching the role of culture, religion and traditions in humanitarian actions, it is important to acknowledge the limits of contextualisation.

\section{THE LIMITS OF CONTEXTUALISATION NEED TO BE CONSIDERED TO UNDERSTAND ORGANIZATIONS' RELUCTANCE}

Understanding the limits of contextualisation from an operational and a legal perspective helps understanding and avoiding risks attached to contextualisation. One of the main issues is the risk of fragmentation of international law: if we accept all beliefs, practices and values at the operational level, it will have a resonance at the international level and international

\footnotetext{
${ }^{46}$ Ashley Currier and Joelle M Cruz, 'Civil Society and Sexual Struggles in Africa' in Ebenezer Obadare (ed), The Handbook of Civil Society in Africa (Springer 2014) 337, 349.

${ }^{47}$ Ferris (n 42).

${ }^{48}$ Nida Kirmani, 'Engaging with Islam to Promote Women's Rights: Exploring Opportunities and Challenging Assumptions' (2011) 11 Progress in Development Studies 87.

${ }^{49}$ Jonathan Benthall, 'Introduction: Faith-Based Organisations as Political, Humanitarian or Religious Actors', Proceedings of the Workshop: Religion, Politics, Conflict and Humanitarian Action Faith-Based Organisations as Political, Humanitarian or Religious Actors, 18-19 May 2005, 5, http://graduateinstitute.ch/files/live/sites/iheid/files/sites/ccdp/shared/Docs/Religion,politics,conflict,humanitaria nism_workhsop\%20proceedings.pdf.
} 
human rights will be impacted. This is why an objective yardstick or a test to decide which beliefs and values should and should not be included when programming is vital.

\title{
2.1 There is a Risk of Fragmentation of International Human Rights with Consequences for Operations and Law
}

Mlay has said that ${ }^{50}$

[t]his search to find cultural underpinnings for the travails of humanitarianism is remarkable in its neglect of any serious exploration of its religious aspects. Thin attempts to do this often create caricatures of religious humanitarianism, and thus perpetuate misunderstanding.

The purpose of this article is to address this gap. However, before I proceed, it is necessary to look at the issues stemming from contextualisation from an operational and legal point of view. While it is clear that context should be taken into account, such a strategy is risky. Contextualising operations might impact the principle of neutrality and impartiality, therefore threatening the work or lives of aid workers. These principles are considered as part of the code of conduct for many organizations and constitute the working ethics of the staff. Such principles should never be tampered with while aid workers should be enabled to take the context into account and be culturally sensitive without taking risks. Brikci, who addresses Bentham's concept of cultural proximity, suggests that aid workers remain sensitive to their environment and develop skills to make them flexible in their work: ${ }^{51}$

\begin{abstract}
'Cultural proximity' is not the answer to the problems of access and insecurity that Western NGOs currently face in countries like Afghanistan and Iraq. What is needed instead is investment in training to infuse in humanitarian workers an interest in learning about frameworks other than their own. This would go some way towards ensuring that anyone could work anywhere.
\end{abstract}

\footnotetext{
${ }^{50}$ Wilfred Mlay, 'Some Myths about Faith-Based Humanitarian Aid', Humanitarian Exchange Magazine, July 2004, http://odihpn.org/wp-content/uploads/2004/08/humanitarianexchange027.pdf.

${ }^{51}$ Nouria Brikci, 'Is Cultural Proximity the Answer to Gaining Access in Muslim Contexts?', Humanitarian Exchange Magazine, March 2005, http://odihpn.org/wp-content/uploads/2005/03/humanitarianexchange029.pdf.
} 
She does not suggest an expertise of the country the staff works in. Such expertise could sometimes raise issues for aid workers who might be tempted to embrace local beliefs and values to understand them better. ${ }^{52}$ Cultural relativism is an occurrence amongst aid workers. Cammack explains how some organizations in Afghanistan would avoid developing programmes solely for women to avoid changing the societal structures; programmes targeting the head of the household would be developing, hoping for a trickle-down effect to touch women. In the case at hand, the argument put forward was that the organization's mandate did not include changing the culture and that any attempt to address women's needs would undermine the stability of the environment needed to manage the programme. ${ }^{53}$ In another situation, Buck and Silver say that

Aid workers expressed a combination of disdain and sympathy (for Somali girls and women in ethnic minorities) in response to what they perceived as oppressive (often gendered) traditional cultural tenets and practices. [...] Forced early marriage and female genital cutting often struck [them] as particularly barbaric and deplorable violations of individual rights. ${ }^{54}$

When discussing whether or not it was the role of aid workers to address such violence, an individual reportedly said that she had abandoned cultural relativism, stating 'if any culture is in need of change, it is Somali culture. ${ }^{55}$, Yet, by refusing to engage with the issue of GBV and culture, the aid worker was indirectly supporting violations as she considered them to be de facto part of the local culture. Cammack speaks of a selective cultural relativism that is directed by organizations' agenda: aid workers will help women if it does not prevent their deployment and activities. ${ }^{56}$

Such attitudes, other than being erroneous and patronising, support cultural relativism; foreign workers then become part of the problem, rather than part of the solution. ${ }^{57}$ They become an active part of the system causing human rights violations on the basis that culture

\footnotetext{
${ }^{52}$ Kris Hulburt, 'Precious Lives Honore to Serve' in Danieli (n 10) 161, 165.

${ }^{53}$ Diana Cammack, 'Gender Relief and Politics During the Afghan War' in Doreen Indra (ed), Engendering Forced Migration: Theory and Practice (Berghahn Books 1999) 94, 103-04.

${ }^{54}$ Patricia Buck and Rachel Silver, 'Tradition, Enlightenment, and the Role of Schooling in Gender Politics Among Somali Girls and Women in Dadaab' in Lesley Bartlett and Ameena Ghaffar-Kucher (eds), Refugees, Immigrants, and Education in the Global South: Lives in Motion (Routledge 2013) 116, 122.

${ }^{55} \mathrm{Id}$.

${ }^{56}$ Cammack (n 53) 104.

${ }^{57}$ Preston D Mitchum, 'Slapping the Hand of Cultural Relativism: Female Genital Mutilation, Male Dominance, and Health as a Human Rights Framework' (2013) 19 William \& Mary Journal of Women and the Law 585; David Rieff, A Bed for the Night: Humanitarianism in Crisis (Simon \& Schuster 2002) 23.
} 
is to be respected or by creating cultural standards, such as tolerance of discrimination, that do not exist in the local values but are created by some to control women. Another example is the existence of many programmes that willingly avoid the inclusion of women to not confront their absence in the public space. ${ }^{58}$ It is interesting to note that I referred to the same example to show a resignation to context, while here it is used to illustrate a disregard for context: it is indeed sometimes difficult to distinguish the two. While it is important to take local beliefs and values into account, one should avoid abiding by them. A legal outcome of supporting unrestricted consideration of traditional, cultural and religious beliefs and values includes fragmentation of international human rights. For example, if an organization accepts the practice of female genital mutilation (FGM) and does not address it because it considers it part of the local culture, this will have an impact at the international level. As a result, several human rights and women's rights would be directly undermined by the attitude endorsing violations in the name of cultural relativism: ${ }^{59}$

[A]ssert[ing] that the practices within any specific culture are unique to the values, systems and practices within that culture. For them, there are no universal standards and the morality and values of one national culture cannot be compared to that of another.

The next question is whether by referring to Muslim human rights and to Muslim humanitarian standards, or any other local readings of these laws, we undermine international law. At the theoretical level, one can argue that including Muslim readings of human rights and humanitarian values in programming could be a threat to the principle of universality. Yet, as I explained elsewhere, ${ }^{60}$ there are Muslim rules regarding humanitarian standards and humanitarian action. There are also Muslims human rights' approaches that are quite similar to those contained in universal values. ${ }^{61}$ These principles are used in the field by FBOs, nonstate armed groups, beneficiaries and religious authorities. Awareness of these principles anchored in religion, culture or traditions is important as it provides relevant information regarding the context aid workers operate in. The issue lies with the treatment of such

\footnotetext{
${ }^{58}$ Cammak (n 53) 103.

${ }^{59}$ Frederick Reese, 'Female Genital Mutilation: An International Crisis That Continues Despite Human Rights Violations', MintPress News, 21 November 2012, http://www.mintpressnews.com/female-genital-mutilation-aninternational-crisis-that-continues-despite-human-rights-violations/41240/.

${ }^{60}$ Anicée Van Engeland, 'Verse 9:5 of the Qur'ān as an Intermixed Ground for Jus ad Bellum and Jus in Bello: Adapting Islamic Classical Theory to Modern Asymmetric Conflict' (2015) 7 GAIR-Mitteilungen 129.

${ }^{61}$ Mashood A Baderin, International Human Rights and Islamic Law (Oxford University Press 2003).
} 
information: while some organizations consider these principles as providing some elements for context, other organizations engage more thoroughly with these values. The purpose of the latter organizations is to negotiate and engage fully with actors on the ground, creating a climate of trust and mutual respect, leading to improved access and protection. Nonetheless, an organization needs to remain aware of the stakes and ensure that the inclusion of values remains informative and does not dictate a policy or strategy at the risk of adapting too much to the context. This is especially relevant when religious values are in contradiction with universal values.

While the risk of fragmentation of international law as the result of the inclusion of beliefs and values is real, a paradox is the indirect promotion of cultural relativism through the rejection of contextualisation that also undermines international law: by opting to ignore beliefs and values to focus solely on aid, some organizations refuse to engage with the context. This is a form of indirect contribution to cultural relativism as it sustains the discrimination in place. Ignoring beliefs and values that contradict universal human rights indirectly encourages socially constructed perceptions regarding 'how men and women interact within a particular society and how they define their roles in that culture' ${ }^{62}$ I argue it even brings such attitudes legitimacy as they are not questioned by neutral outsiders. This questions whether organizations should accept definitions of gender as a social construct and the idea that there are pre-defined roles in society ${ }^{63}$ to ensure neutral access, protection and delivery.

Contextualising can be quite testing: there have been cases of bleeding children brought to foreign organizations, victims of a failed circumcision or of a post-mutilation infection. To avoid such situations, some organizations have chosen to provide clean tools to avoid infection and the propagation of HIV, despite the fact that the organization is opposed to FGM. In another situation, questions have arisen with regard to the traditional sari and long hair Sri Lankan women wear, and that impeded them during the tsunami wave: many died, dragged by the weight of their own clothes and hair. ${ }^{64}$ Aid workers have wondered whether or not they should challenge traditional clothing. Adopting a position has a direct impact on the principle of neutrality as those organizations have had to adapt to the reality of the field to save lives. They have indirectly endorsed a cultural practice, demonstrating that a pure neutral stance towards the context is impossible. Another example can be found in Muslim medical

\footnotetext{
${ }^{62}$ Benjamin (n 19) 157.

63 ibid 156.

${ }^{64}$ Suvendrini Kakuchi, 'In Tsunami, Women Put Modesty Above Survival', Women's eNews, 23 February 2005, http://womensenews.org/story/the-world/050223/tsunami-women-put-modesty-above-survival.
} 
ethics where working as a medical agency in a Muslim country can prove difficult. Taking the context into account raises questions with regard to the composition of a team: should the team include Muslim medical staff? Should we avoid including women on the staff? Or men? What kind of medications can be used? How is privacy an issue? The success of operations depend heavily on the composition of the team: one needs to ensure that there is a gender balance to ensure that there is a male and a female doctor or a male and a female nurse to access patients of both gender. ${ }^{65}$ This helps convincing men taking women to hospitals, as reported female doctor: "we have to fight with men to take women to hospital when necessary'. ${ }^{66}$ As a result, female doctors can be in high demands in some Muslim countries. A third example of the limits of taking context into account is found in the clash between modern medical practices and traditions: how can an NGO address Kur'an Kao Lijek (Qur'an as Healing), widely circulated in Turkey and Bosnia-Herzegovina, which recommends that a sick person write the opening Sura or verse of the Qur'an, leave the paper a glass of water and then drink that water to heal? If a foreign organization respects this tradition, how can it introduce new health techniques or medicines? Would the operational decision to consider the Qur'an as healing be a threat to international values? Does acceptance conflict with the Hippocratic Oath? The MSF approach is that ' $[\mathrm{w}] \mathrm{e}$ treat our patients with dignity, and with respect for their cultural and religious beliefs'. ${ }^{67}$ Yet, the risk when respecting such elements of culture and integrating them into programming is to indirectly support values and beliefs which are in contradiction with human rights. Organizations that embrace culture, traditions and religion might also be perceived as partial and as indirect contributors to cultural relativism. For example, if a foreign organization works closely with a Sunni organization, non-Sunni groups will feel left out. No aid workers wish to be seen as endorsing discrimination or proselytism. ${ }^{68}$ This demonstrates the conundrum aid workers face when it comes to human rights and context in a mission. The integration of values and beliefs improves humanitarian aid. Inclusion, however, has an effect on international law, since beliefs and values that might be contrary to universal human rights might be considered by organizations. Then, if organizations ignore the context, they could also contribute indirectly

\footnotetext{
65 Jenny Hayward-Karlssonand others, Hospitals for War-Wounded: A Practical Guide for Setting Up and Running a Surgical Hospital in an Area of Armed Conflict (International Committee of the Red Cross 1998) 18.

${ }^{66}$ Valentine M Moghadam, Modernizing Women: Gender and Social Change in the Middle East (2nd edn, Lynne Rienner Publishers, 2003) 263.

${ }^{67}$ Medecins Sans Frontieres, 'MSF Charter and Principles', http://www.msf.org/msf-charter-and-principles.

${ }^{68}$ Pamela Lupton-Bowers, 'Teamwork in Humanitarian Missions' in Kevin M Cahill (ed), Basics of International Humanitarian Missions (Fordham University Press and The Center for International Health and Cooperation 2003) 59, 68 .
} 
to the perpetuation of human rights' violations by turning a blind eye. There is therefore a direct link between operational challenges and international law.

There is not a black and white solution to contextualisation and cultural relativism, but I aim at suggesting a middle-ground approach in part 3. I challenge the idea that there is an 'elusive search for a common framework in a world of diversity'. ${ }^{69}$ There is no need to adopt all beliefs, practices and values blindly. This is why a yardstick or a test is needed to determine which beliefs and values can be taken into account.

\subsection{The Necessity of Developing a Yardstick or a Test to Select Values, Beliefs and Practices}

While values, beliefs and practices contribute to understanding the mission's environment, not all of them are to be endorsed if one seeks to respect universal human rights. It is clear that organizations need to comprehend gender roles in a society. Meanwhile, it is not acceptable for such organizations to endorse FGMs, despite arguments put forward by cultural rights' scholars. The consideration of FGMs and other practices challenge universal human rights in a way that leads to the fragmentation of international law. This is why finding an objective yardstick or a test to select acceptable and non-acceptable values is necessary. Guidelines on the extent to which mores could be included are provided, for example, by SPHERE: it offers a compromise in its guidelines by suggesting that organizations '[r]ecruit teams with a balance of women and men, ethnicity, age and social background so that the team's diversity is appropriate to the local culture and context' ${ }^{70}$ The guidelines go further by suggesting that $^{71}$

[t]he planning of hygiene promotion must be culturally appropriate. Hygiene promotion activities need to be carried out by facilitators who have the characteristics and skills to work with groups that might share beliefs and practices different from their own (for example, in some cultures it is not acceptable for women to speak to unknown men).

\footnotetext{
${ }^{69}$ The Centre on Conflict, Development and Peacebuilding, 'Religion and Humanitarianism: Floating Boundaries in a Globalizing World' Conference Report, 10-11 October 2009, 4, http://graduateinstitute.ch/files/live/sites/iheid/files/sites/ccdp/shared/Docs/Publications/Conf_Report_DEF_LR. pdf.

${ }^{70}$ The Sphere Project, Humanitarian Charter and Minimum Standards in Humanitarian Response (3rd edn, 2011) 71.

71 ibid 93.
} 
SPHERE mostly focuses on broad concepts regarding consideration of the Other and the Other's culture; it does not seek to confront local values and beliefs. The purpose remains to support the delivery of aid to the beneficiaries and to maintain a work ethic. Besides, in SPHERE, religion is associated with discrimination and vulnerability, perceiving it solely from a universal human rights' perspective. The approach is purposely generic. As I explained above, the risk is then to indirectly endorse and perpetuate human rights' violations. When a set of pre-departure guidelines including 'do not speak directly to a veiled women' or 'do not look directly at a woman in the eye' is delivered, organizations perpetuate prejudices and do not always reflect the reality; there are places where women have been struggling to play a more important role, using, for example, new readings of the Quran. Their struggle for gender equality will be put at risk by the humanitarian emergency, and possibly undermined by the direct or indirect endorsement of discrimination by aid agencies. As a result, human rights violations are worsened when workers dispatched in the field chose to ignore Muslim women's plight to focus on aid. Aid workers should understand the dynamism that surrounds them so that they can effectively address challenges. SPHERE's awareness of the context remains a step forward, despite the fact that a more thorough cultural mapping is required, especially with regard to staff training. ${ }^{72}$

If we are to argue that cultural-mapping is needed, then it is important to draw an objective line to decide how far an agency can go in incorporating beliefs and values into aid programmes. With the yardstick or test, I suggest addressing issues that are not dealt with directly by the SPHERE guidelines: SPHERE is not able to assist in situations when a female Muslim patient's husband refuses access to help because the medical foreign staff is male and non-Muslim. The guidelines do not address the organization of refugee camps that reflects either tribal divisions or accommodates Muslim single women who have become heads of household to protect them from men. While many would consider such factors to expose the staff to being partial or violating neutrality, these actions constitute contextualisation. This consideration of some values will not only build trust and legitimacy; it will also ensure that it is inclusive of all parties to the conflict or disaster, leading to an improved access to beneficiaries and a better aid delivery. Accommodating single women separately from single men or families in camps is a way of granting protection from sexual violence; dividing a

\footnotetext{
72 Kevin Avruch, 'Culture As Context, Culture As Communication: Considerations For Humanitarian Negotiators' (2004) 9 Harvard Negotiation Review 391, 392; Clémentine Olivier, 'Limiting the Risks and the Vulnerability of Humanitarian Aid Workers' in Danieli (n 10) 211, 216; Brikci (n 51).
} 
refugee camps into ethnic groups is a way of protecting minorities from violence. Nowadays, the prevention of rape in a camp is acknowledged as a priority; it is not seen as a violation of the principle of neutrality and impartiality, and is perceived as part of women's rights. Certainly, such a generic approach is possible when it comes to mores. The United Nations High Commissioner for Refugees (UNHCR) has issued guidelines to protect women refugees, using international law, and states that one of the key issues is the "[p]hysical organization and location of camps to ensure greater protection'. ${ }^{73}$ The UNHCR has reached this conclusion, adopting the stance I argue for: ${ }^{74}$

Relief officials often point to cultural constraints in involving women in decisionmaking, particularly where women have had a limited role in the country of origin. Looking to women as decision-makers under these circumstances, they argue, amounts to tampering with the culture of the group.

These relief officials may, however, have only a superficial understanding of the socio-cultural roles of women. Their concerns may reflect the cultural biases of the officials and/or inadequate understanding of both the traditional cultures and the new circumstances in which refugee women find themselves. Prior to flight, women typically have opportunities to express their concerns and needs, sometimes through their husbands and other times through traditional support networks. In refugee camps, however, many women are unable to participate through such traditional mechanisms as these have broken down. Alternative arrangements must be made to ensure that their voices are heard and the perspectives that they have to offer are included in decision-making.

These comments about the role of women in decision-making can be used to argue that, in some circumstances, single women need special protection when in camps to avoid being subjected to beliefs and values that discriminate against women and to be protected from violence. The UNHCR has also adopted a diversity mainstreaming policy that allows for the consideration of different factors that would turn individuals into 'persons of concern', once

\footnotetext{
73 UNHCR, Guidelines on the Protection of Refugee Women, July 1991, 23, http://www.unhcr.org/3d4f915e4.pdf.

74 ibid 13-14.
} 
all the 'potential implications - positive and negative', have been considered. ${ }^{75}$ This means that ethnic belongings could be included as a factor that could make an individual vulnerable to violence. The UNHCR gender and diversity mainstreaming approach illustrates the culturemapping I argue for: this methodology considers the context while relying on women's rights or the right to physical security, for example. ${ }^{76}$ It is phrased and framed in such a way that contextualisation occurs without threatening neutrality as impartiality. To explain its approach, the UNHCR states it is integral to a rights-based and a community-based approach' ${ }^{77}$ This approach is a solid basis to ensure that no one is left behind. Indeed, my view is that any agenda that does not contextualise risks excluding individuals or communities who define their identity through religion, culture, customs, traditions or customary law, and would not recognise themselves in a non-religious or a-cultural aid strategy.

The issue for anyone doing cultural mapping is to choose which beliefs and values are to be included or excluded. This is why I claim that, further to this UNHCR methodology, inclusion and exclusion need to be decided based on yardstick or a test. This unit of measurement should not be imposed by outsiders, and instead should be an organic solution to local problems. The test or yardstick used to measure which mores are to be kept or not must be the result of the society itself that decides of its own beliefs and values. It is then up to the foreign organization to decide how far they wish to go into considering, including or excluding local mores. The issue at hand for both actors is to know how a dividing line can be established between the rejection of FGMs and the inclusion of female medical staff in a team. What are the differences between both attempts at contextualising? Are the compromises different? It raises some issue of ethics: are aid workers expected to make value judgements as to what is right and what is wrong? This would be problematic as mores themselves could be based upon ideas of right and wrong, the two visions of ethics then clashing. It is crucial for aid workers to take this ethical aspect into account, without providing a value judgement, as mores act as social glue, as people shared values and understandings determining norms. Yet, as Kluckhohn states, it is necessary to decide what is desirable and is not. ${ }^{78}$

\footnotetext{
${ }^{75}$ UNHCR, 'Operational Protection in Camps and Settlements: A Reference Guide of Good Practices in the Protection of Refugees and Other Persons of Concern', UNHCR DIPS and SOSS, 2006, 13, http://www.refworld.org/pdfid/44b381994.pdf.

${ }^{76}$ James C Hathaway, The Rights of Refugees under International Law (Cambridge University Press 2005) 43950 .

${ }^{77}$ UNHCR (n 75) 19.

${ }^{78}$ Clyde Kluckhohn, 'Ethical Relativity: Sic et Non' (1955) 52 Journal of Philosophy 663, 665.
} 
Moral relativism as a technique used to select beliefs and values is not the instrument of choice. This article questions whether we can move away from the moral compass to produce a test or yardstick that would be rather objective.

When analysing legal pluralism and the impact of societal, religious, cultural, traditional norms over the law, the French jurist Carbonnier looks at what he calls the 'infra-droit', the sub-legal systems of minorities living in France and their impact on State law. ${ }^{79}$ My position is different: I examine this idea of infra-law through the eyes of Muslim local communities, since Islam is my case study. I look into cultural, religious, traditional or customary elements justified in terms of Quranic or Prophetic injunctions, based on readings on authoritative legal sources of Islam. My argument is that Muslim tools such as the one of maslaha provide communities and aid agencies with the relevant instrument to make a selection of beliefs, values and practices: maslaha is a legal tool empowering Muslim leaders to select the applicable norm in order to ensure the protection of the public interest. ${ }^{80}$ The leaders are in charge of the selection of mores, using maslaha as a filter. For example, leaders will decide whether a woman in the community should be allowed to re-marry or not, the final decision having an impact on the whole community. Aid workers have come across the use of maslaha in Somali communities, as a filter to solve legal issues amongst refugees. ${ }^{81}$ It has also been used in Daadab, allowing refugees to sort out legal issues by themselves, ${ }^{82}$ such as problems related to inheritance. Maslaha is practiced by community leaders and aims at deciding which beliefs and values stemming from authoritative sources of Islam will or will not be applicable in times of emergency. This Muslim legal concept represents the test or yardstick I seek to promote, encouraging communities to use it to filter mores. For example, the application of Shari'a punishment such as cutting the hand of the thief would be challenged on the ground that it is not beneficial to the community to disable able-bodied individuals, to spread fear of the authorities and to encourage what is internationally acknowledged a cruel form of punishment. ${ }^{83}$ However, it should be stressed that maslaha is not a perfect instrument:

\footnotetext{
${ }^{79}$ Jean Carbonnier, Sociologie Juridique (Themis 1972) 152.

${ }^{80}$ Abdul Aziz bin Sattam, Sharia and the Concept of Benefit: The Use and Function of Maslaha in Islamic Jurisprudence (I B Tauris 2015) xi.

${ }^{81}$ Bram J Jansen, 'Two Decades of Ordering Refugees: The Development of Institutional Multiplicity in Kenya's Kakuma Refugee Camp' in Dorothea Hilhorst (ed), Disaster, Conflict and Society in Crises: Everyday Politics of Crisis Response (Routledge 2014), 114, 120.

${ }^{82}$ Humanitarian Accountability Partnership, 'Care Staff in Dagahaley Camp and Dadaab, Kenya', HAP Standard Review Focus Group Discussion, January 2010.

${ }^{83}$ Abdullahi Ahmed An-Na'im, 'Towards a Cross-Cultural Approach to Defining International Standards of Human Rights: The Meaning of Cruel, Inhuman or Degrading Treatment or Punishment' in Abdullahi Ahmed An-Na'im (ed), Human Rights in Cross-Cultural Perspectives: A Quest for Consensus (University of Pennsylvania Press 1992) 19.
} 
maslaha meetings are often headed by male leaders and can lead to human rights violations. ${ }^{84}$ The maslaha system in Kenya ${ }^{85}$ and in Mauritania ${ }^{86}$ addresses issues of violence against individuals, including GBV. Yet, women wish that men would provide less patriarchal outcomes. This is why the theory new hermeneutics of the Shari'a is crucial: the Muslim reformist movement has encouraged new readings of Islamic authoritative sources but also of the use made of Islamic legal instrument, such as maslaha. The purpose of reformism is to provide readings of the Quran or the Sunna to adapt the message of Islam to the twenty-first century, and it includes attempts at respecting universal human rights. The work of An Na'im is crucial in that regard as he proposes a method to encourage and propagate new readings of Muslim sources. ${ }^{87}$ The respect of international law is possible when the new readings and the universal norms are similar, but problematic when there is a difference. This is why maslaha is so important: it helps leaders completing the work done by those interpreting Muslim texts, directing changes. A dynamic use of maslaha is then necessary and it should be used to address legal matters others than classic Islamic law. It should be used to serve the community, supporting those interpreting Islamic legal sources when they provide liberal and reformist readings. The brief overview of the work of Muslim reformists shows how important it is for foreign organizations to be aware of local debates and the existence of liberal and reformist voices. The selection of relevant mores to consider is consequently a man-made engineered selection guided by beliefs and values the whole community abides by, here God and the authoritative sources of Islam.

Considering that this yardstick is subjective would be correct, as individuals still play a role in the selection and as the context heavily bear on them. One needs to be reminded that western state law is also the result of a subjective process that considered values to be included and left out according to history. Each society structures its values and dictates how people are expected to behave. The key is to ensure that the mores it adopts are, as much as

\footnotetext{
${ }^{84}$ Monica Kathina Juma and Peter Mwangi Kagwanja, 'Securing Refugee from Terror: Refugee Protection in East Africa after September 11' in Niklaus Steiner, Mark Gibney and Gil Loescher (eds), Problems of Protection: The UNHCR, Refugees, and Human Rights (Routledge 2003) 225, 231.

${ }^{85}$ Gladys K Mwangi and Guyo W Jaldesa, 'An Assessment of Sexual and Gender Based Violence in Wajir District, North Eastern Kenya', Reproductive Health Programme, Population Council, January 2009, iv, http://www.svri.org/assessment.pdf.

${ }^{86}$ Equality Now, 'Protecting the Girl Child: Using the Law to End Child, Early and Forced Marriage and Related $\begin{array}{llll}\text { Human Rights January 2014, } & \text { Violations', }\end{array}$ http://www.equalitynow.org/sites/default/files/Protecting the_Girl_Child.pdf.

${ }^{87}$ Abdullahi Ahmed An-Na'im, 'Toward an Islamic Hermeneutics for Human Rights' in Abdullahi A An-Na'im and others (eds), Human Rights and Religious Values: An Uneasy Relationship? (William B Eerdmans Publishing Company 1995) 229.
} 
possible, in line with universal human rights and that aid workers can embrace them as being informative of the local context, without being at risk of violating principles.

The benchmark, once established, needs to be relevant to extreme situations, but also to complex cases. For example, the recent stream of cases of homosexuals condemned to death or imprisonment in Tunisia, Saudi Arabia and Uganda demonstrates the limits of referring to a yardstick that follows human rights and the new hermeneutics of the Shari'a. In Islam, many reformists are reluctant to embrace the right to sexual orientation and gender identity. As a result, the alternative work on proposing new readings of Islam on the topic is limited to a minority of reformists and liberals. This demonstrates that reflecting on a metric system is not enough: when it comes to complex issues, more work needs to be done.

There could be a methodological problem using international human rights law an ideal: the principle of universality of human rights is discussed as these norms have not been objectively selected themselves. To address the first point, the United States and European countries have different understandings of human rights and use different benchmarks to define torture and cruel, inhuman and degrading punishments, or to limit freedom of speech. This is due to the fact that treaties encompassing human rights values remain an ideal to be reached by states. Yet, differences remain in this search for an ideal. It is also true that international human rights are not objective since no clear yardstick was used to decide which rights were included in treaties. They remain, however, the expression of shared common values states want to abide by to uphold peace and security. Consequently, the ideal I opt for is not perfect but it represents an ideal the international community seeks to respect. Far from presenting universal human rights as the problem and as the solution, this article seeks to present them as an ideal to aim for. Additionally, my methodological premise, exposed in previous work, is built on the scholarly work of An Na'im: ${ }^{88}$ Sharia-based beliefs and values must be reformed to be closer in understanding to universal human rights. ${ }^{89}$ New interpretations of Islam then provide support to the normal evolution of beliefs and values. The theory new hermeneutics of the Shari'a also provides a theoretical framework to new interpretations in opposition to a control of norms through conservative and traditional interpretations of Islam. Such reformist approach proposes a new hermeneutics of the Shari'a to close the gap with universal human rights that are then used as a reference.

\footnotetext{
${ }^{88}$ ibid.

${ }^{89}$ Anisseh Van Engeland, 'The Differences and Similarities Between International Humanitarian Law and Islamic Humanitarian Law: Is there Ground for Reconciliation?' (2008) 10 Journal of Islamic Law and Culture 81, 89; Anicée Van-Engeland, 'Bridging Civilizations: The New Hermeneutics of Islamic Law' in Mahmoud Eid and Karim H Karim (eds), Engaging the Other: Public Policy and Western-Muslim Intersections (Palgrave Macmillan 2014) 111.
} 
The purpose of this article is to go beyond the opposition between universalism and cultural relativism. While it is clear that "all members of the human family" share the same inalienable rights', ${ }^{90}$ I disagree with the idea that 'culture is irrelevant to the validity of moral rights and rules' ${ }^{91}$ I also question the idea that 'culture is the sole source of the validity of a moral right or rule' and that there are no common standards, only culturally specific ones. ${ }^{92}$ Instead, I engage with the question of improvement of humanitarian assistance in the field by considering beliefs and values by analysing a third path between universality of human rights and cultural relativism.

\section{FOSTERING A CROSS-CULTURAL COLLABORATION TO IMPROVE AID IN A CONTEXTUALISED ENVIRONMENT}

The creation of a benchmark based on an Islamic legal instrument requires some elaboration before being suggested for use by communities and by aid organizations. The overall aim is to 'enhance what is universal' and to 'respect what is different'. ${ }^{93}$ It is the task of the communities themselves, through a new hermeneutics, explained below, to challenge traditional understandings. Yet, to provide new understandings of religion, the society must firstly be empowered. To do so, I suggest using Benthall's cultural proximity doctrine and to merge it with theories focusing on building bridges between Islam and universal human rights.

\subsection{The Respect of International Human Rights Law through a Local New Hermeneutics}

Awareness of context alone will not bring a solution as to how one can determine which beliefs and values should be kept. This selection of beliefs and values cannot be the role of foreign organizations alone, as this would be compared to a neo-imperialist mission. Instead, work needs to be done within the communities. It is my belief that the beneficiaries

\footnotetext{
${ }^{90}$ Ann Elizabeth Mayer, 'Cultural Particularism as a Bar to Women's Rights: Reflections on the Middle Eastern Experience' in Julie Peters and Andrea Wolper (eds), Women's Rights, Human Rights: International Feminist Perspectives (Routledge 1995) 176.

${ }^{91}$ Jack Donnelly, 'Cultural Relativism and Universal Human Rights' (1984) 6 Human Rights Quarterly 400, 400.

92 ibid.

${ }^{93}$ Imam al Shatibi cited by His Royal Highness Prince El Hassan bin Talal, 'Strategies for disagreement' in Cahill (n 1) 41.
} 
themselves will select values they wish to promote, using, for example, maslaha. The role of foreign organizations will then be to encourage cross-fertilisation while seeking opportunities to empower populations during these changes. While both parties will agree on some human rights as common standards, there will be disagreements: there will be situations where beliefs and values clash with universal human rights law. My suggestion is that in such circumstances, the communities need to rely on socio-cultural theories that examine culture, religion, traditions and customs as living objects that are prone to change and evolution. I, consequently, seek to frame this evolution by looking at the extreme situations of vulnerability. This leads to in-depth transformation during emergency situations.

This perspective of empowering local communities to change the content of beliefs and values is somewhat close to Benthall's idea, but instead of focusing on FBOs, this perspective focuses on beneficiaries: they decide the course of their future. The originality of the argument comes from the fact that the cultural change is prompted and conducted from the bottom-up, supported by the horizontal cultural adaptation between organizations and the community acting as an agent of change. For my argument, I build on the concepts of human agency, ${ }^{94}$ hermeneutics of Shari'a ${ }^{95}$ and cultural legitimacy. ${ }^{96}$ An Na'im has developed a model for an active human agency which encourages a new exegesis of Islam to step away from traditionalism. His argument is that such exegesis produces an organic body of beliefs and values that will change society. Since the transformative agenda is carried out by the human agency itself, and is not imposed by organizations, whatever is produced has local cultural legitimacy. Thus, there is a possibility for Muslims to use instruments based in religion, culture, traditions and customs to propel reforms during a period of crisis. This allows for the respect of an identity while allowing for changes, which, hopefully, will bring Muslim human rights closer to universal human rights, bridging the two sets of law. I use this theory in the context of culture, religion and traditions, proposing to use An Na'im's model to alter some values, practices and beliefs. The role of foreign organizations is then to comprehend local values and beliefs to understand the dynamics at play to avoid supporting cultural relativism.

I suggest that the understandings and approaches to Islam need to be reformed in order to favor the emergence of liberal and reformist interpretations of human rights. This reformed

\footnotetext{
${ }^{94}$ Abdullahi An-Na'im, 'The Best of Times' and 'The Worst of Times': Human Agency and Human Rights in Islamic Societies' (2004) 1(1) Muslim World Journal of Human Rights (no page numbers).

${ }^{95} \mathrm{An}-\mathrm{Na}$ 'im (n 87).

${ }^{96}$ Abdullahi Ahmed An-Na'im, 'Problems of Universal Cultural Legitimacy for Human Rights' in Abdullahi Ahmed An-Na'im and Francis M Deng (eds), Human Rights In Africa: Cross-Cultural Perspectives (The Brookings Institution 1990) 327, 331.
} 
approach to Islam exists within all Muslim communities throughout the world and is therefore an organic solution. Communities that have been affected by conflict or disaster (or both) are in a situation of vulnerability that calls for change. This situation can affect their perceptions of mores, and encourage people to upset established systems. Values, beliefs and practices evolve over time and a big change can provide opportunity for further developments of these beliefs and practices. As stated by Newson et al., '[n]ew cultural characteristics arise and either "survive" and spread through the population or they fade away'. ${ }^{97}$ Consequently, affected populations that are stressed and vulnerable could be more receptive to cultural change if presented in a contextualised fashion..$^{98}$ This approach calls for a shift of perception from a vulnerable party into a pro-active agent playing a role in society. In that regard, the man who loses his status as the bread-winner by being a refugee in a Lebanese camp can witness his wife's empowerment through work. The new circumstances could encourage change rather than falling-back on traditionalism for protection. An example would be the use of the Muslim principle of necessity (darura), another Muslim legal tool, to allow doctors to use forbidden pork-gelatin medications. Local partnerships become then crucial as they are the bridge between foreign organizations and the beneficiaries. ${ }^{99}$ In that regard, Benthall is correct to speak of a cultural proximity. The difference is that I use FBOs and local organizations as a bridge in order to challenge traditional societal injunctions, rather than as the main agent for change.

Barriers and opportunities in the Muslim world are often linked. Obstacles need to be removed at the local level by promoting different Muslim values. In the post-tsunami context, women in Aceh living under the Shari'a rule began to realise that the stricter enforcement of hardline interpretations of Islam was reducing their freedoms. They then worked on developing a women's rights charter which was endorsed by the Governor in 2008. The purpose of this Charter was to demonstrate that Islam is religiously, culturally and traditionally compatible with human rights and that a conservative understanding of the Shari'a needs to be challenged. A law (qanun) was also developed with the support of local women's organizations: it called for gender equality and education but also for monitoring the enforcement of cultural practices in the name of Islam. One important element has been the

\footnotetext{
${ }^{97}$ Lesley Newson, Peter J Richerson and Robert Boyd, 'Cultural Evolution and the Shaping of Cultural Diversity' in Dov Cohen and Shinobu Kitayama (eds), Handbook of Cultural Psychology (The Guilford Press 2007) 454, 456.

${ }^{98}$ UNDP, Bureau for Crisis Prevention and Recovery, 'Disaster-Conflict Interface: Comparative Experiences', PreventionWeb, 2011, http://www.preventionweb.net/files/20432_20432undpdisasterconflictinterface2.pdf.

${ }^{99}$ Katherine Nightingale, 'Building the Future of Humanitarian Aid: Local Capacity and Partnerships in Emergency Assistance', Christian Aid, March 2012, 14, http://www.christianaid.org.uk/images/building-thefuture-of-humanitarian-aid.pdf.
} 
contribution of female clerics to the process: Their interpretations of Islam were taken into account. This illustrates how women can locally support reformist and liberal human rights readings of Islam which allows them to retain their religious, cultural or traditional identity without being oppressed. Their presence and their training to universal human rights has allowed for an organic solution respecting Indonesian local identity to exist while improving their social and private status. It is a positive example of the impact reforms can have when pushed forward by civil society after a disaster and in a conflict zone, Aceh. The support from the local and national government in this effort was crucial, with creation of targetedprograms to support women. Such an approach calls for a shift of perception of the vulnerable party into a pro-active agent.

The combination of An Na'im's work with the concept of cultural proximity leads to positive outcomes with regard to propelling changes in culture, tradition and beliefs. The importance of supporting such changes - or at least being aware of their existence when programming - gives the opportunity to enhance access, protection and delivery for foreign organizations that will then operate in an aid-friendly environment. This is the result of crossfertilisation when all actors involved collaborate and have an impact on each other's culture. The outcomes of this model of contextualisation are positive for all: foreign organizations can lead successful missions; local FBOs and groups can play an effective role; and beneficiaries become actors. The result is a better operational environment where considering mores do not become a burden, a risk or an attempt to fragment international law. Reformed culture, religion and traditions become the vehicle for the improvement of aid and contribute to a better respect and enforcement of universal human rights law.

An illustration of this cross-cultural approach to humanitarian assistance can be found in rehabilitation and development: ${ }^{100}$ this approach to humanitarian aid is defined as 'multidimensional and proactive with broad, complex parameters that focus on the rehabilitation and development of a vulnerable population through addressing bio-psycho-socio-economic factors within the cultural milieu'. ${ }^{101}$ The idea is to contextualise by relying on local organizations to build capacity. To be successful '[d]eep immersion in the culture and collaboration with the host government and other stakeholders by aid workers is necessary to identify and prioritise needs and set goals that will maintain/improve health and well

\footnotetext{
${ }^{100}$ Janice K Kopinak, 'Humanitarian Aid: Are Effectiveness and Sustainability Impossible Dreams?', Journal of Humanitarian Assistance, 10 March 2013, http://sites.tufts.edu/jha/archives/1935. 101 ibid.
} 
being'. 102 Other examples of collaboration include the World Food Programme's Memorandum of Understanding signed with the Organization of the Islamic Conference to deliver food aid in parts of Somalia. ${ }^{103}$ The next part suggests the optimal situations for merging the two approaches.

\subsection{Empowerment Generated during Conflict and Disaster is an Opportunity to Promote Locally Driven Changes}

If organizations consider the cultural or religious context within reasonable limits, a climate of trust and understanding can be created, thus facilitating access and encouraging collaboration between foreign organizations and local populations. Before this dialogue occurs, I believe it is crucial to re-create the interrupted natural flow of changes and reforms: cultural or religious values are prone to changes. Yet, in traumatic situations, affected populations tend to give an over-arching role to static readings of religion and understandings of culture, traditions and customs. During time of vulnerability, individuals and communities tend to fall back on conservative values and beliefs on the path to resiliency. ${ }^{104}$ This is why it is crucial to understand the religion, culture, traditions and/or customs they will turn to as it will influence the beneficiaries' behavior: ${ }^{105}$

[V]ulnerabilities and the effect of an often volatile context all contribute to people being vulnerable for different reasons and in different ways. Vulnerable people, like all those affected by disaster, have various capacities to manage and recover from disasters. A thorough understanding of vulnerable people's capacities and the barriers they may face in accessing humanitarian support is essential for a response that meets the needs of those who need it most.

\footnotetext{
102 ibid.

103 James Shaw-Hamilton, 'Cross-Cultural Collaboration: Building Partnerships', Humanitarian Exchange Magazine, April 2011, http://www.odihpn.org/humanitarian-exchange-magazine/issue-50/cross-culturalcollaboration-building-partnerships.

${ }^{104}$ International Federation of the Red Cross, 'World Disasters Report 2014: Focus on Culture and Risk', http://www.ifrc.org/Global/Documents/Secretariat/201410/WDR\%202014.pdf; Jean-Christophe Gaillard and Pauline Texier, 'Religions, Natural Hazards, and Disasters: An Introduction' (2010) 40(2) Religion 81; Andreana Reale, 'Acts of God(s): The Role of Religion in Disaster Risk Reduction', Humanitarian Exchange Magazine, October 2010, http://odihpn.org/wp-content/uploads/2010/08/humanitarianexchange048.pdf.

105 SPHERE (n 69) 54.
} 
It has emerged that affected populations that are stressed and vulnerable could be more receptive to cultural changes if presented in a contextualised fashion. ${ }^{106}$ Recent research on the cross-over between conflict and disaster has demonstrated that such events create not only resilience but also venues to work on gender matters. ${ }^{107}$ Encouraging and supporting women to endorse new gender roles while supporting their religious values means that we actually acknowledge a natural process of empowerment which, in turn, will enable vulnerable populations to become decision-makers. Consequently, taking the context into account not only creates an environment which facilitates access and delivery, but it also helps beneficiaries in re-positioning themselves with regard to culture and religion and to engage in a critical pro-active stance. This has positive outcomes on universal human rights: as culture, religion and other values and beliefs evolve, using the human rights' benchmark, bridges are created between the two legal systems, domestic and universal. This means that the changes operated by local agencies and considered by foreign organization directly impact international law.

As stressed by UNDP, disasters and conflicts offer the opportunity to shed light on cultural, traditional and religious issues. ${ }^{108}$ During crises, women become vulnerable, and even more so if the state or the community originally has gender imbalance. Their human rights may not have been respected in the pre-crisis or pre-disaster society, and their rights may be furthered risked in the aftermath of an event. Sometimes, women benefited from gender equality before a crisis, but the events changed the situation for the worst. This is why organizations delivering humanitarian assistance need to know about the context to understand the obstacles women have faced prior to the events, and assess the current situation. The need for context-based programming is thus crucial during humanitarian emergencies. In Aceh, after the tsunami, social disorganization as well as the sudden disappearance of daily indicators led to abuses. Single women and widowed women were the victims of sexual violence, demonstrating yet again that temporary shelter increases a woman's vulnerability. Those women were disadvantaged and vulnerable due to the loss of their protectors which could be their husband, the in-laws or the community as a whole. The second level of vulnerability occurred after sexual abuses: abused women were stigmatised for failing to uphold Muslim standards of dignity and modesty. There were also attempts at controlling and gendering the public space in Aceh according to so-called Islamic precepts;

\footnotetext{
${ }^{106}$ UNDP, Bureau for Crisis Prevention and Recovery, 'Disaster-Conflict Interface: Comparative Experiences', PreventionWeb, 2011, http://www.preventionweb.net/files/20432_20432undpdisasterconflictinterface2.pdf. 107 ibid. 108 ibid.
} 
the religious local police and morality squads subsequently gained power. They began accusing single or widowed women of lacking modesty, restricting them to living indoors. This condemned them to a social death but also a physical death as they would become dependent on others for money and food. In 2009, the Aceh Legislative Council enacted the Qanun Jinayah (Islamic penal code) which justified cruel punishments such as the stoning of women for adultery, in the name of Islam, culture and traditions. These attempts at gendering society and controlling women were supported by local Shari'a groups and judges, who propagated hardline interpretations of Islam: it was, for example, argued that women's lack of modesty had caused the tsunami and that the wave had been sent as a punishment by God. Ethiopian and Sudanese Muslim women are also social outcasts once raped during crises because they have brought shame to their family and community. In each case above, the disaster or conflict provided the space for groups supporting traditionalist and hardline interpretations of Islam to act in a fragile environment. These examples demonstrate again why it is so important to contextualise a mission. Organizations must be aware of the stakes and be able to adopt a policy towards human rights' violations. If they are not aware of the context, they might give the impression they endorse cultural relativism.

The occurrence of conflicts and natural disasters at concomitant periods of time has affected women in Bangladesh, Afghanistan, Indonesia, Pakistan, Somali and Sudan, to name a few. Muslim women are therefore as vulnerable as any others. They are vulnerable to all forms of GBV, which does not differ for women around the world who are not Muslims. The additional strain, stemming from religion, pertains to yet another level of vulnerability which affects Muslim women. They also do suffer from some specific issues resulting from interpretations made of Islam. The interpretations of Islam are made by clerics or scholars to clarify the Qur'an and the Sunna for all believers. They influence local mores, giving Qur'anic verses a traditional or hardline content. As a result, women who find themselves cross-over of a conflict and a disaster can sometimes be victimised twice: they are victims of regular gender abuses occurring at the interface between disasters and conflict. They can also be victims of their religious, cultural, traditional or customary environment. Some groups, communities or authorities will indeed use this state of vulnerability caused by conflict and disaster to seek control of women via Islam. Somalian women are vulnerable due to drought and conflict as they take the risk of being raped when they fetch water far the camps. Besides GBV, they also experience a more local form of violence, justified by traditions and Islam. For example, FGMs affect the majority of the female population. There is a strong belief that Islam dictates the mutilations, belief which results from interpretations made regarding the 
concept of honor and modesty. There are reports that FGMs have been practiced on girls as young as five years old in conflict areas. In difficult times of drought and conflict, FGMs become a cause for celebration and festivity, which is a form of social catharsis. Besides, FGMs are perceived as a way of guaranteeing a girl's access to marriage as her chastity and honor remain intact, despite the fact that the social environment is affected by war and natural disasters. FGMs are also perceived as a way of keeping the community together during difficult times. While in neutral programming, women would be the focus of attention, their culture, religion or tradition is also included in a context-based programming to understand the stakes. The purpose is then to ensure that women are still present in the public sphere and protected in the private sphere. Taking into account the needs of Muslim women at the interface between conflict and disaster or during a single event (conflict or disaster) raises the issue of contextualisation of access, protection and delivery. Such a strategy will promote attempts to protect vulnerable women while respecting these women's environment. The ultimate purpose is to prevent situations in which women are caught between local values and universal values.

\section{CONCLUSION}

The suggestion put forward in this article is to enable foreign organizations to be as efficient as possible when delivering aid and seeking to access beneficiaries. I argue that contextualisation, by taking into account beliefs and values, can improve humanitarian aid, as long as there is a selection of mores considered. The latter takes the shape of a filter that measure which beliefs and values is to be considered by organizations and locals. I rely on the cultural proximity doctrine to develop my argument. I also address the stake of the transformative agenda; rather than arguing in favor of a transformation operated by foreign organizations, I suggest that beneficiaries use a context of crisis as an opportunity to challenge the status quo and I stress that aid organizations need to be aware of the dynamics of the context to adapt to the local transformative agenda. Consequently, opportunities exist to see the aid workers change their approach in order to facilitate access to and protection of beneficiaries as well as improving the delivery of aid. The same opportunities give beneficiaries the opportunity to challenge the environment they live in, empowering them with control at times where all is lost. When looked at from that angle, traditions, culture and religion do not constitute a hindrance to access, protection and delivery, but part of the 
solution. While contextualisation is still controversial, it does offer opportunities; it also creates an ethical conundrum while can be sorted via the creation of a benchmark.

While many organizations will show reluctance to engage with context or to have a transformative impact, the reality of the field and of the needs of the beneficiaries should be considered. This challenges the traditional views of neutrality and impartiality, as the approach examined above demands a level of involvement from aid organizations. This is why establishing a yardstick remains crucial: it helps ensuring that aid organizations do not forfeit their impartial and neutral stance, or are perceived as doing so. This explains why so many aid workers reject the idea of contextualisation. 